https://www.ipp.npu.edu.ua/ua/2013-02-20-07-2917/515-viktoriia-som URL:

3. Профессионально-трудовое воспитание

http://www.surgu.ru/attachment/3940/download/profe ssionalno-trudovoe-vospitanie.doc

4. Ціннісне ставлення до праці. URL: http://golovanivsk-

nvk.edukit.kr.ua/informaciya_pro_zaklad/vihovna_rob ota/cinnisne_stavlennya_do_praci/

\section{REFERENCES}

1. Los', YU. (1998). Formyrovanye otnoshenyya $k$ trudu kak tsennosty $u$ uchashchykhsya peduchylyshch. [Formation of the attitude to work as values in the students of pedagogical schools]. Armavyr.

2. Som, V. (2013). Osoblyvosti formuvannya tsinnisnoho stavlennya do pratsi u ditey molodshoho shkil'noho viku. [Peculiarities of formation of value attitude to work in children of primary school age] URL: https://www.ipp.npu.edu.ua/ua/2013-02-20-0729-17/515-viktoriia-som

3. Professyonal'no-trudovoe vospytanye. [Professional and labor education] URL: http://www.surgu.ru/attachment/3940/download/profe ssionalno-trudovoe-vospitanie.doc

4. Tsinnisne stavlennya do pratsi. [Value attitude to work]. URL: http://golovanivsknvk.edukit.kr.ua/informaciya_pro_zaklad/vihovna_rob ota/cinnisne_stavlennya_do_praci/

\section{ВІДОМОСТІ ПРО АВТОРА \\ КУчАЙ Тетяна Петрівна доктор педагогічних наук, професор кафедри педагогіки і психології, Закарпатський угорський інститут ім. Ференца Ракоці II.}

Наукові інтереси: ціннісне ставлення до праці в процесі виховання особистості.

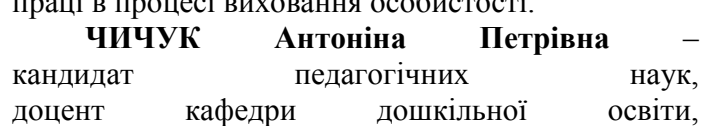
доцент кафедри дошкільної освіти, Черкаський національний університет імені Богдана Хмельницького.

Наукові інтереси: ціннісне ставлення до праці в процесі виховання особистості.

ШИНКАРУК Василь Дмитрович - доктор філологічних наук, професор, декан гуманітарнопедагогічного факультету Національного університету біоресурсів і природокористування України.

Наукові інтереси: теоретичні засади інклюзивного навчання в Україні.

\section{INFORMATION ABOUT THE AUTHOR}

KUCHAY Tatyana Petrivna - Doctor of Pedagogical Sciences, Professor of the Department of Pedagogy and Psychology, Transcarpathian Hungarian Institute. Ferenc Rakoti II.

Circle of scientific interests: the value attitude to work in the process of personal education.

CHICHUK Antonina Petrovna - Candidate of Pedagogical Sciences, Associate Professor of the Department of Preschool Education, Cherkasy National University named after Bogdan Khmelnitsky.

Circle of scientific interests: the value attitude to work in the process of personal education.

SHYNKARUK Vasylyi Dmytrovych - Doctor of Philology, Professor, Dean of the Faculty of Humanities and Pedagogics National University of Life and Environmental Sciences of Ukraine.

Circle of scientific interests: theoretical principles of inclusive learning in Ukraine.

Стаття надійшла до редакиї 23.11.2019 p.

ПОДОПРИГОРА Наталія Володимирівна доктор педагогічних наук, доцент, доцент кафедри природничих наук та методик їхнього навчання Центральноукраїнського державного педагогічного університету імені Володимира Винниченка

ORCID: https://orcid.org/ 0000-0002-4092-8730 e-mail: npodoprygora@ukr.net

\title{
ФОРМУВАННЯ ГОТОВНОСТІ МАЙБУТНІХ УЧИТЕЛІВ ПРИРОДНИЧИХ НАУК ДО РЕАЛІЗАЦЇ̈ ЦИКЛУ НАУКОВОГО ПІЗНАННЯ ЗАСОБАМИ НАВЧАЛЬНОГО ФІЗИЧНОГО ЕКСПЕРИМЕНТУ
}

\begin{abstract}
Постановка та обгрунтування актуальності проблеми. Перехід вищої освіти України на нові показники якості освіти (компетентності) актуалізували потребу в фахівцях здатних забезпечувати сприятливі умови для всебічного розвитку суб'єктів освітнього процесу. У цьому
\end{abstract}

контексті особливої уваги заслуговує реформування процесу підготовки майбутніх фахівців, професійна діяльність яких спрямована на формування в студентів цілісних уявлень про систему природничих наук, що водночас потребує не лише базових природничо-математичних знань і умінь, а й 
таких, що забезпечують здатність майбутнього вчителя до їхньої реалізації у професійній діяльності, готовності до інновацій як у змісті, так i технологіях навчання природничих наук.

При цьому слід ураховувати, що формування готовності майбутніх фахівців до професійної діяльності особливо тісно пов'язано 3 національними пріоритетами i реформуванням середньої освіти України в контексті реалізації концептуальних засад нової української школи. До однієї 3 ключових компетентностей Нової української школи віднесено основні компетентності у природничих науках і технологіях - наукове розуміння природи і сучасних технологій, а також здатність застосовувати його в практичній діяльності [1]. що актуалізує потребу розроблення спеціальних методологічних засад щодо формування в учнів практичних умінь застосовувати науковий метод, спостерігати, аналізувати, формулювати гіпотези, збирати дані, проводити експерименти, аналізувати результати.

Аналіз останніх досліджень і публікацій. У працях вітчизняних i зарубіжних учених проблему формування готовності майбутнього вчителя природничих наук розглянуто 3 різних позицій: загальні основи впровадження компетентнісного підходу в професійну підготовку майбутніх учителів фізики (П. С. Атаманчук, О. І. Іваницький, В. Д. Шарко та ін.); теоретичні основи формування компетентності особистості інтегрованої здатності розв'язувати життєві, а згодом - професійні завдання (М. С. Головань, I. Г. Срмаков, А. I. Кузьмінський, О. I. Пометун та ін.); психологічні основи розвитку ключових компетентностей (Г. О. Балл, І. А. Зимня, О. О. Хуторський та ін.); методологічні засади формування і розвитку професійної компетентності в навчанні теоретичної фізики (О. А. Коновал, I. О. Мороз, В. В. Мултановський та ін.), формування в студентів фізико-технічних знань і вмінь $\begin{array}{ll}\text { (I. Т. Богданов, } & \text { В. П. Вовкотруб, }\end{array}$ А. В. Касперський, О. С. Мартинюк, та ін.); теоретико-методичні основи формування інформаційно-комунікаційних

компетентностей

(Ю. П. Бендес, В. Ф. Заболотний та ін.). Розробленню питання формування та розвитку професійної компетентності майбутніх учителів і викладачів фізики сприяли наукові дослідження 3 проблем навчання фізики в загальноосвітній школі: ознайомлення учнів 3 методами наукового пізнання (О. І. Ляшенко, М. Т. Мартинюк,

В. Г. Разумовський,
М. І. Садовий та ін.); розвитку в учнів загальнонавчальних

(Л. Ю. Благодаренко, умінь I. В. Бургун, В. Д. Сиротюк й ін.), реалізація задачного підходу в навчанні фізики (C. У. Гончаренко, Є. В. Коршак, А. І. Павленко та ін.). Проте виявлення методичних особливостей відзеркалення циклу наукового пізнання в контексті формуваггя готовності майбутніх учителів природничих наук потребують спеціальних досліджень

Метою статті $\epsilon$ висвітлення методичних особливостей формування готовності майбутніх учителів природничих наук до реалізації циклу наукового пізнання засобами навчального фізичного експерименту.

Виклад основного матеріалу дослідження. Досвід викладання курсів, загальної і теоретичної фізики, методики навчання фізики в педагогічному університеті дозволяє нам стверджувати, що традиційна схема формально-логічного niдxодy, не повною мірою забезпечує виконання сучасних вимог підвищення якості природничо-наукової освіти оскільки поза пї увагою залишаються: по-перше, - проблема індивідуального особистісного розвитку студентів щодо формування: мотивації, інтересу, соціалізації, самостійності і творчості у навчанні. По-друге, що важливо для навчання фізики - це проблема формування емпіричного i теоретичного знання 3 урахування багатоплановості й розмаїття змісту навчання фізики в його організаційно-процесуальних аспектах. На наш погляд, для створення моделі квазіпрофесійної діяльності вчителя фізики в методичних курсах природничих наук важливими є результати наукових досліджень попередників, які пройшли ефективну перевірку практикою їх упровадження в загальноосвітню школу.

Зокрема за радянських часів відомою, в аспекті формування творчих здібностей учнів в галузі фізико-технічної творчості та винахідництва є робота В. Г. Разумовського, якому вдалося відшукати достатньо універсальний (методологічний) інструмент для організації навчального пізнання принųun ичиклічності, який дає змогу чітко побудувати етапи навчально-пізнавальної діяльності учнів з фізики за схемою, яка віддзеркалює логіку наукового пізнання природи. Він представлений наступною логікою організації навчально-пізнавальної діяльності: «факти, проблема - гіпотеза, модель - наслідок - експеримент, практика» [4]. Принцип циклічності у явній і неявній формі $\epsilon$ нормою пізнання, що конкретизується для двох провідних видів 
навчальної діяльності - експериментування та моделювання, що $є$ апроксимованими від методів наукового пізнання фізичних явищ $\mathrm{i}$ процесів - експериментального і теоретично, останні у фізиці $€$ рівноправними $\mathrm{i}$ взаємодоповнюваними.

Проблемі формування теоретичних узагальнень фізичних знань присвячені роботи В. В. Мултановського, який запропонував проектування змісту навчання здійснювати за універсальною схемою структури фізичної теорії. При цьому в змісті навчання виділяються фундаментальні явища, а потім викладаються їх теорії, 3'ясовується їх практичне значення та перспективи подальшого розвитку [3]. Механізм узагальнення в розвитку теоретичного мислення суб'єктів навчання забезпечується принципом генералізації, який водночас зумовлює значне розширення змісту навчання, що потребує відшукання механізмів балансування цього процесу.

У вітчизняній науковій методичній школі розв'язанню проблеми взаємозв'язку теоретичного та емпіричного в навчанні фізики відомим є дослідження О. І. Ляшенка, який розглядає цей зв'язок ширше ніж співвідношення рівнів пізнання i виділяє декілька напрямів, відповідно до яких ним обгрунтовано методичну модель формування в учнів фізичного знання на новій концептуальній основі єдності змістового i процесуального компонентів навчального процесу, що дало змогу розв'язати проблему на нових теоретико-методичних засадах [2].

Разом 3 тим, для організації освітнього процесу засобами навчання фізики, методична модель єдності змістового i процесуального компонентів потребує врахування пізнавального потенціалу методу наукового пізнання, зокрема це дає змогу обгрунтувати об'єктивність взаємозв'язку теоретичного та емпіричного в навчанні фізики, що в загальноосвітній школі реалізовано на засадах аналогії наслідків емпіричних спостережень та узагальнень 3 теоретичними основами фізики. Отже, розвиваючи ідеї попередників, розв'язання проблеми віддзеркалення в навчальному пізнанні методу наукового пізнання ми вбачаємо у концептуальній ідеї єдності змісту і методів навчання фізики у інтегрованому взаємозв'язку їхньої фундаментальної і методичної підготовки майбутніх учителів природничих наук в контексті професійної діяльності [4].

Розв'язання проблеми віддзеркалення в освітньому процесі методів наукового пізнання ми вбачаємо у концептуальній ідеї єдності змісту і методів навчання фізики у інтегрованому

взаємозв'язку фундаментальної і методичної підготовки майбутніх учителів в контексті їхньої професійної діяльності.

Методика навчання циклу наукового пізнання складають кілька ключових аспектів. По-перше, перехід від фактів до моделі має здійснюватися в спільній діяльності вчителя з учнями, без посилань на авторитети, всіляко заохочуючи їх самостійність до висунення правдивих гіпотез. По-друге, при переході від наслідків теорії до умов експерименту варто ознайомити учнів 3 сучасними умовами i можливостями експериментування. По-третє, система експериментів, яка обгрунтовує фізичну теорію, має складати демонстраційні, лабораторні форми навчального експерименту та виконання додаткових експериментальних завдань, що забезпечує організацію ефективної навчальнопізнавальної діяльності, включаючи i науково-дослідну роботу.

Оптимальною $є$ ситуація, коли навчальний експеримент тісно пов'язаний із теоретичними основами вивчення досліджуваного фізичного процесу або явища. Це означає, що такий експеримент носить не ілюстративний, а доказовий характер, і його результат дає вичерпне пояснення. Цим загострюється проблема забезпечення достатньої експериментальної підготовки вчителя фізики i наявності відповідної експериментальної бази щодо жорсткої вимоги присутності навчального експерименту практично на кожному уроці, кожному занятті [5].

У процесі наукового пізнання перехід від фактів до моделі і від наслідків до експерименту носять інтуїтивний характер, тому саме вони визначають сутність мислення учнів з фізики. Розв'язування задач 3 фізики також сприяє розвитку мислення учнів. Проте розрахункові задачі досліджують лише теоретичні моделі явища і не торкаються глибинних процесів, які формують мислення 3 фізики. Іншими словами можна навчитись розв'язувати задачі, але не навчитись фізиці.

Дещо інакшою виглядає ситуація пов'язана із розв'язуванням експериментальних задач, в яких побудові теоретичної моделі передує експериментальний пошук фактів щодо формулювання умови такої задачі, або коли отриманий результат теоретичного розв'язку підтверджує експеримент. Кожна 3 таких задач відповідно до видів навчального експерименту може бути реалізованою у демонстраційному або фронтальному 
варіанті, бути частиною науково-дослідної роботи тощо. Постановка i виконання навчального фізичного експерименту потребує необхідних умов щодо його реалізації. Створюючи умови експерименту, необхідно підготувати обладнання, зібрати експериментальну установку й нарешті виконати належним чином експеримент. Отримуючи результат у процесі спостереження явища, необхідно звертати увагу на основні його риси, за можливості отримати кількісну характеристику досліджуваного явища. Проводячи аналіз, вміти зіставляти отриманий результат із результатами інших експериментів, пояснювати його і прогнозувати нові явища. Розглянемо один із варіантів реалізації циклу наукового пізнання на прикладі експериментального завдання «Визначення добротності математичного маятника».

Обладнання: 1) Установка, зібрана на базі цифрових вимірювальних приладів [5]; 2) Електронні терези; 3) Лабораторний штатив 3 муфтами; 4) Лінійка; 5) Пусковий електромагніт, джерело постійного струму, кнопковий вимикач, провідники.

Зміст $i$ виконання завдання. Якщо коливальна система (маятник нитяний, маятник пружний, коливальний контур і ін.) виконує вільні коливання (рухається лише під дією внутрішніх сил), то іiі коливання $€$ гармонічними. Але практично будь-яка коливальна система насправді здійснює затухаючі клювання, коли відхилення іiі від положення рівноваги поступово зменшуються. Такі коливання є негармонійними (амплітуда коливань втрачає зміст, частота в буквальному розумінні також). Проте, коли коливання затухають слабко (наприклад, сила тертя значно менша сили пружності), то затухаючі коливання розглядаються близькими до синусоїдальних, та разом такими, що мають змінну амплітуду і умовний період коливань. Наразі амплітуда коливань - це величина максимального відхилу системи від положення рівноваги, яка через рівні проміжки часу утворює спадну геометричну прогресію.

Умовний період - це проміжок часу між двома послідовними максимальними відхиленнями від положення рівноваги в одну й ту ж сторону. Тоді:

$$
x(t)=A_{0} e^{-\beta t} \cos \left(\omega t+\alpha_{0}\right),
$$

де $A_{0}$ - початкова амплітуда (у момент часу $t=0), \beta-$ коефіцієнт затухання, $\omega-$ умовна частота затухаючих коливань, причому:

$$
A=A_{0} e^{-\beta t}, \omega=\sqrt{\omega_{0}^{2}-\beta^{2}}, \mathrm{a}
$$

$$
\omega_{0}=\sqrt{\frac{k}{m}}, \beta=\frac{c}{2 m},
$$

де $c$ - коефіцієнт тертя: $F_{T}=-c \mathrm{v}-$ сила в'язкого тертя, яка лінійно пропорційна швидкості коливань).

Що потрібно розуміти під виразом «слабке затухання»? Для цього водять кількісну характеристику ступеня затухання - добротність коливальної системи.

Основною причиною, збурення коливань, є квазіпружна сила $F_{\Pi}=-k x$, а основна причина затухань - сила тертя $F_{T}=-c \mathrm{v}$.

Добротність системи $Q-$ це характеристика системи i оточуючого середовища, що визначається відношенням максимальної сили пружності до максимальної сили тертя, тобто:

$$
Q=\frac{F_{\Pi}}{F_{T}}=\frac{k x_{\max }}{c \mathrm{v}_{\max }}
$$

$$
\text { Але } x_{\max }=A, \quad \text { a } \quad \mathrm{v}_{\max }=\omega_{0} A \text {. }
$$

Ураховано, що $\beta$ - мала, а тому $\omega \approx \omega_{0}$.

Отже:

$$
Q=\frac{k}{c \omega_{0}}=\frac{m \omega_{0}^{2}}{c \omega_{0}}=\frac{m \omega_{0}}{c}=\frac{\sqrt{k m}}{c} .
$$

Експериментальне вимірювання добротності коливальної системи потребує непрямих вимірювань, а тому не $є$ наочним для навчального експериментування з фізики. Ми пропонуємо використати інший підхід i обрати за основу інше визначення добротності коливальної системи.

Для системи, яка являє собою математичний маятник, добротність коливальної системи визначається як відношення ii повної енергії $W$ до величини втрати енергії за чверть періоду $W_{1}$ внаслідок iii дисипації (втрата енергії за рахунок роботи сили тертя). Тоді для добротності такої системи можна записати

$$
Q=\frac{W}{W_{1}} .
$$

Виконання експерименту зводиться до відшукання повної механічної енергії маятника, яку він мав на початку коливань, та втрати частки цієї енергії протягом чверті періоду його вільного коливання.

Ідея досліду полягає у дослідженні коливального руху нитяного маятника. Активна частина експериментальної установки являє собою штатив, до стінки якого за допомогою стержня підвішують на нитці металеву кульку. Нижче закріпленого стержня з маятником аналогічно закріплений другий стержень так, щоб нитка у вертикальному положенні (рівноваги 
маятника) торкалась стержня (рис. 1). Початкове положенні маятника - це його розташування в положенні горизонтально натягнутої нитки. Висота, за початкового відхилення маятника, дорівнюватиме його довжині $l$. Коли кульку відпустити, вона буде прагнути до положення рівноваги, досягнувши яке, маятник довжини $l$ матиме обмеження $з$ боку нижнього стержня (нитка зачіпається за нижній стержень) і коливання продовжуватимуться але вже як маятник із меншою довжиною (меншою на відстань між стержнями на штативі, наприклад, на $l_{1} / 2$ (рис. 2).

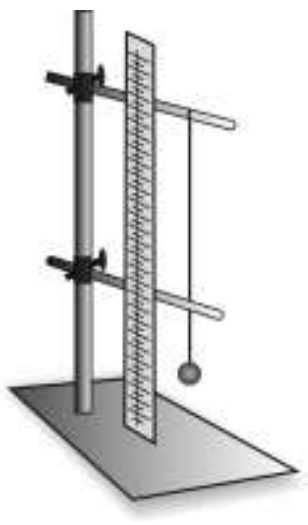

Рис. 1

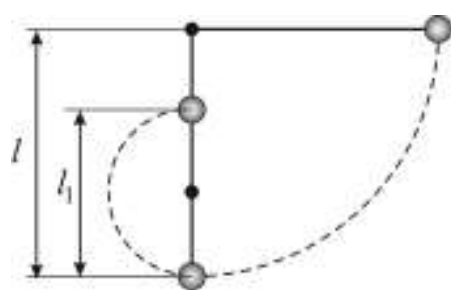

Рис. 2

Змінюючи віддаль, можна очікувати декілька наслідків: кулька може описати коло або частину кола навколо нижнього стержня; може досягнути верхнього положення вертикально розташованої натягнутої нитки i, зупинившись на мить, впасти вертикально униз під впливом сили тяжіння до компенсації ऑiі силою натягу. Останній наслідок $є$ цікавим тим, що втрату повної механічної енергії маятника можна обрахувати без врахування його кінетичної енергії.

Початкове значення механічної енергії системи розраховують за формулою

$$
W=m g l \text {, }
$$

де $l$ - уся довжина маятника.

Значення енергії при наступному досягненні кулькою верхнього вертикального положення:

$$
W=m g l_{1},
$$

де $l_{1}$ - висота, на яку підніметься маятник, досягнувши свого вертикального положення.

Враховуючи, що розглядуваний коливальний процес складає половину періоду коливань маятника (дві чверті періоду), тоді втрату енергії за чверть періоду можна записати як

$$
\Delta W=\frac{m g\left(l-l_{1}\right)}{2} .
$$

Отже, за пропонованих умов виконання експерименту, добротність коливальної системи визначають як

$$
Q=\frac{W}{\Delta W}=\frac{2 m g l}{m g\left(l-l_{1}\right)}=\frac{2 l}{l-l_{1}} .
$$

Таким чином, виконання експериментальної частини зводиться до визначення положення нижнього стержня, за якого кулька, досягнувши вертикального положення, не продовжуватиме свого руху по колу.

Експериментальну частину роботи можна реалізувати за допомогою експериментальною установки зібраної на базі цифрових вимірювальних приладів [6], з пристроєм для утримування і пуску нитяного маятника, рис. 2. Для цього на штативі закріплюють пусковий електромагніт, в якості якого використовують електромагніт з лабораторного комплекту для складання електромагнітного реле. Для електроживлення можна використати будь яке джерело постійного струму із напругою 4-6 В. В якості вимикача зручніше взяти кнопковий, який має вільно замкнуті контакти.

Кінець нитки маятника кріплять до вантажу, який перебуває на терезах. До іншого кінця нитки, перекинутої через блоки установки, кріпиться металева (залізна) кулька.

На стержні штатива кріплять горизонтальний стержень. На останньому кріплять електромагніт так, щоб він утримував кульку відхиленого маятника за горизонтального розташування нитки. Нижче на стержні цього ж штатива кріпиться тонкий стержень так, щоб середина вертикально розташованої нитки підвісу маятника в положенні рівноваги торкалась стержня 3 правого боку. До цього ж стержня прив'язаний кінець іншої нитки, яка в натягнутому стані іншим кінцем закріплена на повзунку штангенциркуля (між шайбами 3 допомогою гвинта).

Виконання експерименту зводиться до визначення повної механічної енергії маятника, яку він мав на початку коливань, та втрати частки цієї енергії протягом чверті 
періоду його вільного коливання.

Початкове положення маятника положення за горизонтально натягнутої нитки, де кулька утримується електромагнітом. Відповідно висота за початкового відхилення дорівнює довжині $l$, яку ретельно вимірюють лінійкою. Коли натисканням кнопки кульку відпускають, маятник починає здійснювати коливання i, досягнувши положення рівноваги, коливання маятника продовжуватимуться, але з меншою довжиною $l / 2$. Змінюючи відстань $l$, i вимірюючи піi зміну за допомогою штангенциркуля, досліджують наслідки, коли кулька описує: коло; частину кола навколо нижнього стержня; досягає верхнього положення вертикально розташованої натягнутої нитки i, зупинившись на мить, впасти вертикально вниз під впливом сили тяжіння. Останній випадок є цікавим тим, що втрату повної механічної енергії маятника можна обрахувати без врахування його кінетичної енергії згідно формули (8).

Отже виконання експериментальної частини зводиться до вимірювання 3 належною точністю величини зміщення стержня, за який зачипається підвіс, від положення половини довжини маятника, що забезпечується використанням цифрового штангенциркуля.

Іншого характеру набуває виконання завдання за вимірюванням сили, що діє на кульку при проходження положення рівноваги через $1 / 2$ періоду, $3 / 2$ періоду й інше. Цю силу фіксують за стрибками показань електронних терезів, на табло яких в початковий момент встановлюють нулі. Дослід повторюють по кілька разів, фіксуючи значення максимальних показань i визначаючи середне значення для кожного досліду.

Пропонований

варіант експериментального відображення затухаючих механічних коливань $є$ доступним і доцільним також для доповнення формування коливально-хвильового концентру у змісті курсу фізики профільної школи.

Висновки та перспективи подальших розвідок напряму. Готовність майбутнього вчителя природничих наук до професійної діяльності 3 фізики забезпечується: психологічною - навчально-пізнавальними та професійними мотивами, інтересами та цінностями; теоретичною - уявленнями про практико-орієнтовані проблеми фізики, що розв'язуються засобами навчання фізики, фізичними й методологічними знаннями; практичною - уміннями 3 досвіду пізнавальної діяльності, спеціальними експериментаторськими уміннями та особистісним досвідом діяльності. Здатність до діяльності є системою вмінь, які в своїй єдності й забезпечують здатність до ефективної продуктивної самокерованої навчально-пізнавальної діяльності, спрямованої на розв'язання навчальних i професійно орієнтованих завдань засобами їхнього навчання. 3 цих позицій перспективним $\epsilon$ продовження дослідження щодо розроблення матеріалів, що забезпечать самостійну навчально-пізнавальну діяльність майбутніх учителів природничих наук засобами навчання хімії, біології та географії в контексті змісту інтегрованого курсу «Природничі науки» старшої профільної школи.

\section{СПИСОК ДЖЕРЕЛ}

1. Концепція нової української школи [Електронний ресурс] / Міністерство освіти i науки України : Нова українська школа. - Режим доступу : http://mon.gov.ua/activity/

education/zagalna-serednya/ ua-sch-2016/ konczepcziya.html

2. Ляшенко О. І. Взаємозв'язок теоретичного та емпіричного у навчанні фізики : дис. ... доктора пед. наук : 13.00 .04 - професійна підготовка; 13.00 .02 - методика навчання фізики / Ляшенко Олександр Іванович. К., 1996. - 442 с.

3. Мултановский $\quad$ B. B. Проблема теоретический обобщений в курсе физики средней школы : автореф. дис. на соискание науч. степени доктора пед. наук: спец. 13.00.02 «Теория и методика обучения и воспитания (физика)»/В. В. Мултановский. М, 1979. - 44 с.

4. Подопригора Н. В. Методична система навчання математичних методів фізики у педагогічних університетах : Монографія / Н. В. Подопригора; МЛН України ; КДПУ ім. В. Винниченка. Кіровоград : ФО-П Александрова М. В., 2015. - 512 с.

5. Разумовский В. Г. Проблема развития творческих способностей учащихся в процессе обучения физике : дис. ... доктора пед. наук: 13.00 .02 (ф) / Разумовский Василий Григорьевич. M., 1972. $-507 \mathrm{c}$.

6. Podoprygora N. Organization and realization of the experimental cycle of scientific cognition at Physics study [Electronic resource] / Podoprygora Natalia // Latin-American Journal of Physics Education. 2014. Vol. 8. No. 1, March. pp. 13-21.

\section{REFERENCES}

1. Kontseptsiia novoi ukrainskoi shkoly. [Elektronnyi resurs] / Ministerstvo osvity i nauky Ukrainy : Nova ukrainska shkola. - Rezhym dostupu : http://mon.gov.ua/activity/ education/zagalnaserednya/ ua-sch-2016/ konczepcziya.html 
2. Liashenko, O. I. (1996). Vzaiemozviazok teoretychnoho ta empirychnoho u navchanni fizyky. [The relationship between theoretical and empirical in teaching physics]. Kyev.

3. Multanovskyi, V. V. (1979). Problema teoretycheskyi obobshchenyi $v$ kurse fyzyky srednei shkoli. [The problem of theoretical generalizations in the course of high school physics]. Moscow.

4. Podoprygora, N. (2015). Metodychna systema navchannia matematychnykh metodiv fizyky $u$ pedahohichnykh universytetakh. [Methodical system of teaching mathematical methods of physics at pedagogical universities]. Kirovohrad.

5. Razumovskyi, V. H. (1972). Problema razvytyia tvorcheskykh sposobnostei uchashchykhsia $v$ protsesse obuchenyia fyzyke. [Methodical system of teaching mathematical methods of physics in pedagogical universities]. Moscow.

6. Podoprygora, N. (2014). Orhanizatsiya ta realizatsiya eksperymental'noho tsyklu naukovoho piznannya pry vyvchenni fizyky. [Organization and realization of the experimental

УДК 378:004

DOI:10.36550/2415-7988-2019-1-185-47-51 cycle of scientific cognition at Physics study]. LatinAmerican Journal of Physics Education.

\section{ВІДОМОСТІ ПРО АВТОРА}

ПОДОПРИГОРА Наталія Володимирівна - доктор педагогічних наук, доцент, завідувач кафедри природничих наук та методик їхнього навчання Центральноукраїнського державного педагогічного університетц імені Володимира Винниченка.

Наукові інтереси: професійна освіта, теорія та методика навчання фізики.

INFORMATION ABOUT THE AUTHOR

PODOPRYGORA Nataliia Volodymyrivna Doctor of Pedagogical Sciences, Associate Professor, Heard of Department of Natural Sciences and their Teaching Methods of Volodymyr Vynnychenko Centralukrainian State Pedagogical University.

Circle of scientific interests: professional education, theory and methods of teaching (Physics).

Стаття надійшла до редакиії 23.12.2019 p.

РОМАНЕНКО Тетяна Василівна доктор педагогічних наук, доцент кафедри автоматизації та комп'ютерно-інтегрованих технологій

Черкаський національний університет імені Богдана Хмельницького ORCID: https://orcid org/: 0000-0002-9790-2718 e-mail: bod_t@ukr.net

\section{ПРОФЕСІЙНА ПІДГОТОВКА МАЙБУТНЬОГО ВЧИТЕЛЯ ІНФОРМАТИКИ ТА ФІЗИКИ ЗАСОБАМИ ІНФОРМАЦЙНО-КОМУНІКАЦЙНИХ ТЕХНОЛОГІЙ}

\begin{abstract}
Постановка та обгрунтування актуальності проблеми. Важливим завданням процесу підготовки вчителя інформатики та фізики за допомогою засобів інформаційно-комунікаційних технологій (IКT) $\epsilon$ процес забезпечення психологопедагогічними та методичними розробками, за допомогою яких можна створити найоптимальніші умов упровадження засобів інноваційних ІКТ для інтенсифікації процесу навчання, збільшення його ефективності та якісних показників.
\end{abstract}

Аналіз останніх досліджень i публікацій. Дослідженням застосування інформаційно-комунікаційних технологій в освіті присвячені роботи Войтовича I. C., Жалдака М. І., Карташової Л. А., Співаковського О. В., Русіної Н. Г.

Проблемами використання IKT на уроках інформатики та фізики займаються такі провідні науковці, як: Наумейко Г. Г., Наумейко О. М., Шолом Г. І., Щур В. О., та інші. Питаннями професійної підготовки майбутнього вчителя інформатики займаються Жалдак М. І., Морзе Н. В., Раков С. А., Триус Ю. В. та інші. Але безліч питань залишаються не вирішеними, зокрема, не повністю вирішена проблема упровадження інформаційно-комунікаційних технологій у процесі професійної підготовки майбутнього вчителя інформатики та фізики в закладах вищої освіти $[3 ; 10 ; 11]$.

Мета статті - дослідження процесу застосування інформаційно-комунікаційних технологій під час професійної підготовки майбутнього вчителя інформатики та фізики в закладах вищої освіти.

Виклад основного матеріалу дослідження. Сучасні педагоги серйозно займаються створенням та застосуванням концепції впровадження інформаційнокомунікаційних технологій в закладах вищої освіти (ЗВО). Тому, практично всі галузі набувають розвиту, який грунтований на масовому використанні IКT.

Саме вчитель інформатики та фізики 